\title{
Abdomen flipping of Apis dorsata breviligula worker bees correlated with temperature of nest curtain surface*
}

\author{
Jerzy WOYKE ${ }^{\mathrm{a}}$, Jerzy WILDE ${ }^{\mathrm{b}}$, Maria WILDE $^{\mathrm{b}}$, Cleofas CERVANCIA $^{\mathrm{c}}$ \\ ${ }^{\text {a }}$ Apicultural Division, Agricultural University, Warsaw, Poland \\ b Apicultural Division, Warmia-Mazury University, Olsztyn, Poland \\ ${ }^{c}$ Institute of Biological Science, University of the Philippines, Los Baños, Philippines
}

Received 19 July 2005 - Revised 14 December 2005 - Accepted 6 January 2006

\begin{abstract}
Apis laboriosa and Apis dorsata worker bees in the curtain covering the nest comb perform dorso-ventral abdomen flipping (AF). Relationship between percentage of bees performing $\mathrm{AF}$ and the nest surface temperature $\left(t_{c}\right)$ or ambient temperature $\left(t_{a}\right)$ was investigated on A. dorsata breviligula nests in the Philippines. When both temperatures dropped down the \%AF increased. Partial correlation showed, that the correlations between $\% \mathrm{AF}$ and $\mathrm{t}_{\mathrm{c}}$ were about 4 times higher than between $\% \mathrm{AF}$ and $\mathrm{t}_{\mathrm{a}}$. This support the hypothesis that worker bees of the mantle of the curtain, which perform AF, react rather to the temperature around them in the surface of the curtain than to ambient temperature some distance apart.
\end{abstract}

Apis dorsata / abdomen flipping / nest curtain / temperature correlation / Philippines

\section{INTRODUCTION}

Apis laboriosa Smith and Apis dorsata Fabr. worker bees in the curtain covering the nest comb perform dorso-ventral abdomen flipping (AF). Some colonies perform AF throughout each day. The high rates of performance of those movements suggest that they play an important role in the life of the colonies. Woyke et al. (2004) suggested that AF of workers of the mantle of the curtain might provide a signal for the bees inside the nest, indicating the need for heating. They suggested also that many contractions of muscles raising the abdomen might produce some heat. Woyke et al. (2004) found that the percentage of workers performing AF increased when ambient temperature $\left(t_{a}\right)$ decreased. However, in some cases, the intensity of AF changed although $t_{a}$ did not. Therefore, in the present investigation we tested the suggestion of Woyke et al. (2004) that the intensity of AF is more closely correlated with the temperature of the

Corresponding author: J. Woyke, jerzy_woyke@sggw.pl

* Manuscript editor: Walter S. Sheppard surface of the curtain $\left(t_{c}\right)$ rather than with $t_{a}$. As far we know, the temperature of the mantle of $A$. dorsata nest curtains has not been examined.

\section{MATERIALS AND METHODS}

Two nests of A. dorsata breviligula Maa were observed, one 1 March 2004 in Los Baños (alt. $50 \mathrm{~m}$ ), and the other from 4-6 March in Alfonso (alt. $600 \mathrm{~m}$ ), the Philippines. The activities of worker bees on the surface of the nest curtains were recorded with a video camera recorder from a distance of $1 \mathrm{~m}$. The records were made during 3 min, mostly when $t_{a}$ changed by $1{ }^{\circ} \mathrm{C}$. All together, 21 records were made. On the screen, 5 rows of worker with 12 bees in each row (altogether 60) were visible. Worker bees performing AF during $3 \mathrm{~s}$ were counted on a TV screen. The ratio of this number, to the total number of bees visible on the screen, gave the $\%$ of bees performing AF. The counts were repeated 10 times, giving a total of 210 observations. Within the 1260 bees examined, $508 \mathrm{AF}$ of worker bees were recorded. Ambient temperature $\left(\mathrm{t}_{\mathrm{a}}\right)$ was recorded with electronic thermometer placed in shade $1 \mathrm{~m}$ above ground near 
the nest. Also the temperature of the outer layer of bees of the nest curtain was measured with the aid of an external thermocouple inserted between those bees. Proportions were arcsine transformed prior to statistical analysis.

\section{RESULTS}

Figure 1 shows that $t_{c}$ was not constant. In Los Baños, when $t_{a}$ was $35^{\circ} \mathrm{C}$ or higher then $t_{c}$ was lower than $\mathrm{t}_{\mathrm{a}}$. However, when $\mathrm{t}_{\mathrm{a}}$ was $34^{\circ} \mathrm{C}$ or lower, then $\mathrm{t}_{\mathrm{c}}$ was higher than $\mathrm{t}_{\mathrm{a}}$. In Alfonso, $\mathrm{t}_{\mathrm{a}}$ was below $29^{\circ} \mathrm{C}$ during all 3 days of observation. In this condition, $\mathrm{t}_{\mathrm{c}}$ was always higher than $\mathrm{t}_{\mathrm{a}}$.

When $t_{a}$ decreased in both study sites by $17^{\circ} \mathrm{C}$, (from $37^{\circ} \mathrm{C}$ to $20^{\circ} \mathrm{C}$ ), then $\mathrm{t}_{\mathrm{c}}$ decreased only by $9.4{ }^{\circ} \mathrm{C}$ (from $35.4{ }^{\circ} \mathrm{C}$ to $26^{\circ} \mathrm{C}$ ). Thus, the variation was lower in $\mathrm{t}_{\mathrm{c}}$ than in $\mathrm{t}_{\mathrm{a}}$.

Paired t-tests showed that in Los Baños at high $\mathrm{t}_{\mathrm{a}}\left(\overline{\mathrm{X}}=33.5^{\circ} \mathrm{C}\right)$ no significant difference was found between $\mathrm{t}_{\mathrm{c}}\left(34.5^{\circ} \mathrm{C}\right)$ and $\mathrm{t}_{\mathrm{a}}(\mathrm{t}=$ $0.57, P=0.58)$. However, in Alfonso at lower $\mathrm{t}_{\mathrm{a}}\left(\overline{\mathrm{X}}=24.0^{\circ} \mathrm{C}\right)$, the three daily means of $\mathrm{t}_{\mathrm{c}}$ $\left(\overline{\mathrm{X}}=28.2\right.$ to $28.9^{\circ} \mathrm{C}$ ) were highly significantly higher than $\mathrm{t}_{\mathrm{a}}(\mathrm{t}=9.68-12.97$, all $P<0.0003)$.

The correlation between $t_{a}$ and $t_{c}$ in Los Baños at high $\mathrm{t}_{\mathrm{a}}(\mathrm{r}=0.95, P<0.0001)$ was slightly lower than in Alfonso at lower $\mathrm{t}_{\mathrm{a}}$ (all 3 $\mathrm{r}=0.99, P<0.0001)$. Nevertheless, changes at $t_{c}$ in both conditions, were highly and significantly correlated with changes in $t_{a}$. Both, the significant difference between $t_{c}$ and $t_{a}$ at lower $t_{a}$, as well as the high correlation between them, shows that the value of $t_{c}$ was the result of the interaction of the high brood nest temperature $\left(\overline{\mathrm{X}}=31-33^{\circ} \mathrm{C}\right)$ and the lower $\mathrm{t}_{\mathrm{a}}$.

$\mathrm{AF}$ of curtain workers was not observed at ambient temperatures above $30{ }^{\circ} \mathrm{C}$ in Los Baños, when no significant difference was found between $t_{a}$ and $t_{c}$. However, AF were recorded at $\mathrm{t}_{\mathrm{a}}$ below $29{ }^{\circ} \mathrm{C}$ in Alfonso when significant differences were found between $t_{a}$ and $t_{c}$. When $t_{a}$ decreased from 28 to $20{ }^{\circ} \mathrm{C}$ and $t_{c}$ from 30.7 to $26{ }^{\circ} \mathrm{C}$ the percentage of workers performing $\mathrm{AF}$ increased significantly from $1.7 \%$ to $14.8 \%$ (Fig. 1).

During all 3 days in Alfonso, high correlations were found between $\% \mathrm{AF}$ and both $t_{a}$ and $t_{c}$ (Tab. I). The correlations were little higher between $\% \mathrm{AF}$ and $\mathrm{t}_{\mathrm{c}}$, than between
$\% \mathrm{AF}$ and $\mathrm{t}_{\mathrm{a}}$. The R-Squared statistics were in the tree days little higher for $\% \mathrm{AF}$ and $\mathrm{t}_{\mathrm{c}}$, than for $\% \mathrm{AF}$ and $\mathrm{t}_{\mathrm{a}}$. This suggested that the $\mathrm{R}$-Squared statistics for $\mathrm{t}_{\mathrm{c}}$, explained the $\% \mathrm{AF}$ variability better than the $\mathrm{R}$ statistics for $\mathrm{t}_{\mathrm{a}}$.

To get a clearer indication which of the independent variables the $t_{a}$ or the $t_{c}$ has the greatest effect on the dependent $\% \mathrm{AF}$ variable, additional calculations were made. Partial correlation showed, that the correlations were in particular days 3.3-4.8 times $(\overline{\mathrm{X}}=3.9)$ higher between $\% \mathrm{AF}$ and $\mathrm{t}_{\mathrm{c}}$ than between $\% \mathrm{AF}$ and $t_{a}$ (Tab. I). The P-values for $r$ of $\% A F$ and $t_{c}$ presented only a fraction of $0.2-0.4$ of those values for $t_{a}$. This indicates higher confidence level for $t_{c}$ than $t_{a}$ correlations. Partial correlation was also calculated for all the data from the tree days pulled together, taking into account the day variable as well. The correlation between $\% \mathrm{AF}$ and $\mathrm{t}_{\mathrm{c}}: \mathrm{r}=-0.445, P=0.028$, $\mathrm{df}=17, \mathrm{~N}=21$, was statistically significant and was 3.0 times stronger than between \% AF and $\mathrm{t}_{\mathrm{a}}: \mathrm{r}=-0.149, P=0.271$, which was not significant.

Multiple regressions analysis was also calculated for the dependent \% AF variable and both independent variables, the $t_{a}$ and $t_{c}$. The multiple regression model to describe the relationship between the three variables was; $\% \mathrm{AF}=70.56-1.88 \mathrm{t}_{\mathrm{c}}-0.48 \mathrm{t}_{\mathrm{a}}$. The multiple regression analysis showed that the $\mathrm{P}$-values for the relationship between $\% \mathrm{AF}$ and $\mathrm{t}_{\mathrm{c}}$ variables presented only a fraction of 0.2 to 0.4 of the values for \%AF and $t_{a}$ (Tab. I.) This indicates higher confidence level for $t_{c}$ then for $t_{a}$.

Since the highest P-values belonged to $t_{a}$, the Stat Advisor of the statistical program Statgraphics 4.1 suggested, to consider removing the $t_{a}$ variable from the model, to simplify it.

\section{DISCUSSION}

Partial correlation showed that the percentage of bees performing AF was about 4 times stronger correlated with $t_{c}$ then with $t_{a}$. The $\mathrm{P}$-values for correlations between \% AF and $\mathrm{t}_{\mathrm{c}}$ presented only a fraction of 0.3 of P-values for $\% A F$ and $t_{a}$. Similarly, multiple regression analysis showed that $\mathrm{P}$-values for relationship between $\% \mathrm{AF}$ and $\mathrm{t}_{\mathrm{c}}$ variable presented also 

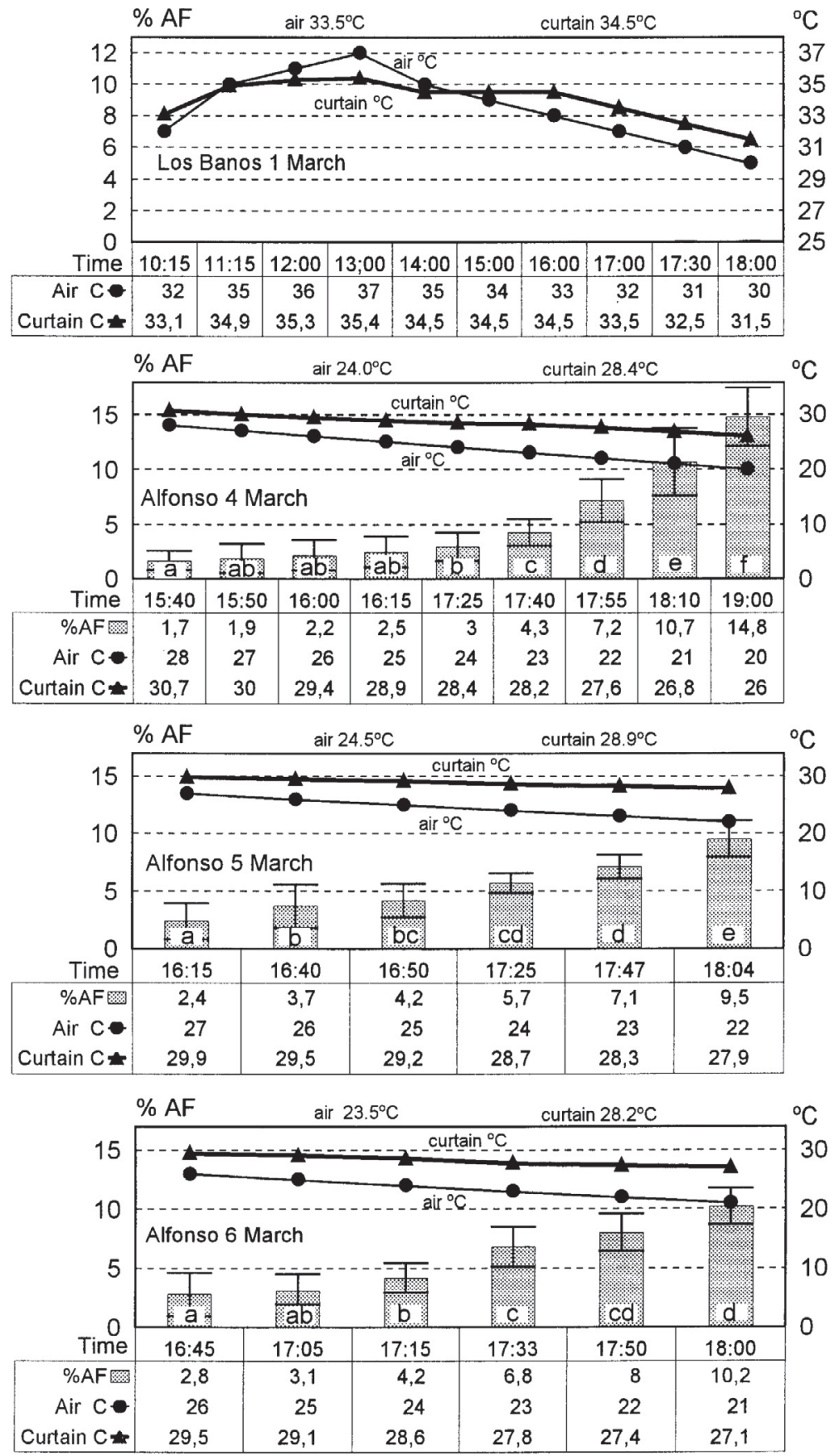

Figure 1. Percentage of worker bees performing abdomen flipping (AF) in relation to air and curtain surface temperatures. Bars - means of 10 repetitions. Different letters at the bottom of the bars indicate significant differences between means. Error vectors present SD. Data above the upper frame lines indicate daily mean air and curtain temperatures. 
Table I. Relationship between percentages of bees performing abdomen flipping (\% AF) and both temperatures: ambient $\left(\mathrm{t}_{\mathrm{a}}\right)$ and surface of nest curtain $\left(\mathrm{t}_{\mathrm{c}}\right)$.

Correlation: $r$ simple, or $r$ partial and multiple regression analysis.

\begin{tabular}{|c|c|c|c|c|c|c|}
\hline & 4 March & & 5 March & & 6 March & \\
\hline & $r$ & $P^{*}$ & $r$ & $P$ & $r$ & $P$ \\
\hline \multicolumn{7}{|l|}{ r simple } \\
\hline $\mathrm{t}_{\mathrm{a}}$ & -0.930 & 0.000 & -0.992 & 0.000 & -0.985 & 0.000 \\
\hline$t_{c}$ & -0.941 & 0.000 & -0.994 & 0.000 & -0.992 & 0.000 \\
\hline $\mathrm{R}$-squared $\% \mathrm{t}_{\mathrm{a}}$ & 86.4 & & 98.4 & & 96.9 & \\
\hline $\begin{array}{l}\mathrm{R} \text {-squared } \% \mathrm{t}_{\mathrm{c}} \\
\mathrm{r} \text { partial }\end{array}$ & 88.6 & & 98.9 & & 98.4 & \\
\hline $\mathrm{t}_{\mathrm{a}}$ & -0.126 & 0.383 & -0.191 & 0.379 & -0.150 & 0.405 \\
\hline$t_{c}$ & -0.421 & 0.149 & -0.578 & 0.154 & -0.715 & 0.087 \\
\hline$t_{c} / t_{a}$ & 3.3 & 0.4 & 3.7 & 0.4 & 4.8 & 0.2 \\
\hline mult. regression & t-stat. & & t-stat. & & t-stat. & \\
\hline$t_{a}$ & 0.312 & 0.766 & 0.336 & 0.759 & 0.263 & 0.810 \\
\hline$t_{c}$ & -1.137 & 0.299 & -1.227 & 0.307 & -1.770 & 0.175 \\
\hline$t_{c} / t_{a}$ & & 0.4 & & 0.4 & & 0.2 \\
\hline
\end{tabular}

$P=P$-value of statistical significance.

only a fraction of 0.3 of $P$ for relationship between $\% \mathrm{AF}$ and $\mathrm{t}_{\mathrm{a}}$. Thus, both types of $P$-values indicated higher confidence level for $\mathrm{t}_{\mathrm{c}}$ than for $\mathrm{t}_{\mathrm{a}}$. Hence, statistical calculations indicate that the curtain temperature has greater effect on the percentage of bees performing AF than air temperature has. This support the suggestion of Woyke et al. (2004) that $t_{c}$ is related with $\% \mathrm{AF}$ closer and explains the variability in \% AF better than $t_{a}$ does.

Certainly, worker bees of the mantle of the curtain, which perform AF, react rather to the temperature around them in the surface of the curtain than to ambient temperature some distance apart.

Résumé - Corrélation du battement de l'abdomen des ouvrières d'Apis dorsata breviligula avec la température à la surface du rideau d'abeilles. Les ouvrières d'Apis laboriosa et Apis dorsata présentes dans le rideau qui couvre le rayon du nid exécutent un battement dorso-ventral de l'abodomen (AF), qui semble jouer un rôle important dans la vie des colonies. Ce pourrait par exemple être un signal pour les abeilles à l'intérieur du nid leur indiquant le besoin de chauffer. Nous avons étudié si la température ambiante $\left(\mathrm{t}_{\mathrm{a}}\right)$ ou la température de la surface du nid $\left(t_{c}\right)$ était corrélée au pourcentage d'abeilles qui exécutaient un battement de l'abdomen (\% AF). Deux nids d'A. dorsata breviligula ont été observés du $1^{e r}$ au 6 mars 2004 dans la région de Los Baños, Philippines. L'activité des abeilles à la surface du rideau $t_{\mathrm{a}} \mathrm{a}$ été enregistrée avec une caméra vidéo à $1 \mathrm{~m}$ de distance et les températures $t_{a}$ et $t_{c}$ avec un thermomètre électronique. Parmi les 210 enregistrements, 1260 abeilles ont été examinées, dont 508 exécutaient un AF. La figure 1 montre que lorsque $t_{a}$ est égale ou supérieure à $35^{\circ} \mathrm{C}, \mathrm{t}_{\mathrm{c}}$ est inférieure à $\mathrm{t}_{\mathrm{a}}$ mais lorsque $\mathrm{t}_{\mathrm{a}}$ est inférieure ou égale à $33^{\circ} \mathrm{C}, \mathrm{t}_{\mathrm{c}}$ est alors supérieure à $\mathrm{t}_{\mathrm{a}}$. Lorsque $t_{a}$ et $t_{c}$ sont toutes deux au-dessus de $31^{\circ} \mathrm{C}$, les ouvrières n'exécutent pas d'AF. En-dessous de cette température, on observe pourtant le comportement. Lorsque la température chute, le pourcentage d'AF augmente. Le tableau I donne la corrélation (r) durant $3 \mathrm{j}$ entre $\% \mathrm{AF}$ et $\mathrm{t}_{\mathrm{a}}$ d'une part et $\% \mathrm{AF}$ et $t_{c} d$ 'autre part, ainsi que les corrélations partielles. Celles-ci sont environ 4 fois plus fortes pour \% AF et $\mathrm{t}_{\mathrm{c}}$ que pour $\% \mathrm{AF}$ et $\mathrm{t}_{\mathrm{a}}$. Cela indique que la température du rideau a une influence plus grande que la température ambiante sur le pourcentage d'abeilles qui exécutent un $\mathrm{AF}$ et cela corrobore l'hypothèse de Woyke et al. (2004) selon laquelle les ouvrières qui exécutent un $\mathrm{AF}$ réagissent plutôt à la température autour d'elles à la surface du rideau qu'à la température ambiante. Apis dorsata / battement de l'abdomen / corréla-
tion avec la température / Philippines

Zusammenfassung - Das Abdomenschnippen bei Apis dorsata breviligula Arbeiterinnen korreliert mit der Oberflächentemperatur des Bienenvorhangs im Nest. Apis laboriosa und Apis dorsata Arbeiterinnen im Bienenvorhang der Nestoberfläche zeigen ein dorso-ventrales Schnippen des Abdomens, ein Verhalten das eine wichtige Rolle im Leben der Kolonie zu haben 
scheint. Es könnte beispielsweise ein Signal für Bienen im Nest darstellen, dass geheizt werden muss. Wir untersuchten, ob und wie gut die Umgebungstemperatur $\left(t_{a}\right)$ oder die Temperatur der Nestoberfläche $\left(t_{c}\right)$ mit dem Prozentsatz der Bienen korreliert, die ein Abdomenschnippen zeigen (\%AF). In der Region von Los Baños auf den Philippinen wurden vom 1.-6. März 2004 zwei A. dorsata breviligula Nester beobachtet. Die Aktivitäten der Arbeiterinnen auf der Oberfläche des Nestvorhangs wurden mit einer Videokamera im Abstand von $1 \mathrm{~m}$ aufgezeichnet, und $\mathrm{t}_{\mathrm{a}}$ und $\mathrm{t}_{\mathrm{c}}$ wurden mittels eines elektronischen Thermometers registirert. In 210 Videoaufnahmen zeigten 508 von insgesamt 1260 beobachteten Bienen ein AF Verhalten. Abbildung 1 zeigt, dass $t_{c}$ niedriger war als $t_{a}$, wenn $t_{a} 35^{\circ} \mathrm{C}$ oder mehr betrug. Wenn jedoch $\mathrm{t}_{\mathrm{a}}$ unter $33{ }^{\circ} \mathrm{C}$ lag, dann war $\mathrm{t}_{\mathrm{c}}$ höher als $\mathrm{t}_{\mathrm{a}}$. Wenn sowohl $t_{\mathrm{a}}$ als auch $\mathrm{t}_{\mathrm{c}}$ bei über $31{ }^{\circ} \mathrm{C}$ lagen, zeigten die Arbeiterinnen im Nestvorhang kein AF. Unter dieser Temperatur wurde das Verhalten jedoch beobachtet. Mit abnehmender Temperatur stieg der Prozentsatz an AF-Bienen an. Die Korrelation zwischen \%AF und $\mathrm{t}_{\mathrm{a}}$ schwankte innerhalb der 3 Tage von $\mathrm{r}=-0.930$ bis $\mathrm{r}=-0.985$, und zwischen $\%$ AF und $t_{c}$ von $r=-0.941$ bis $r=-0.994$ (Tab. I). Die partiellen Korrelationen zwischen \%AF und $\mathrm{t}_{\mathrm{a}}$ schwankten innerhalb der 3 Tage jedoch zwischen $\mathrm{r}=-0.126$ und $\mathrm{r}=-0.383$, und für $\% \mathrm{AF} \mathrm{zu} \mathrm{t}_{\mathrm{c}} \mathrm{zwi}-$ schen $r=-0.421$ und $r=-0.715$. Demzufolge waren die partiellen Korrelationen ( $\mathrm{r}$ ) zwischen \%AF und $t_{c}$ etwa viermal höher als zwischen \%AF und $t_{\mathrm{a}}$. Dies bedeutet, dass die Temperatur im Bienenvorhang einen grösseren Effekt auf den Prozentsatz der AF-Bienen zu haben scheint als die Umgebungstemperatur und stützt damit die Hypothese von Woyke (2004), dass Arbeiterinnen, die ein AFVerhalten zeigen, stärker auf die Temperatur in der unmittelbaren Nestumgebung reagieren als auf die Lufttemperatur.

Apis dorsata / Abdomenschnippen / Nestvorhang / Temperaturkorrelation / Philippinen

\section{REFERENCES}

Woyke J., Wilde J., Wilde M. (2004) Temperature correlated dorso-ventral abdomen flipping of Apis laboriosa and Apis dorsata worker bees, Apidologie 35, 493-502. 